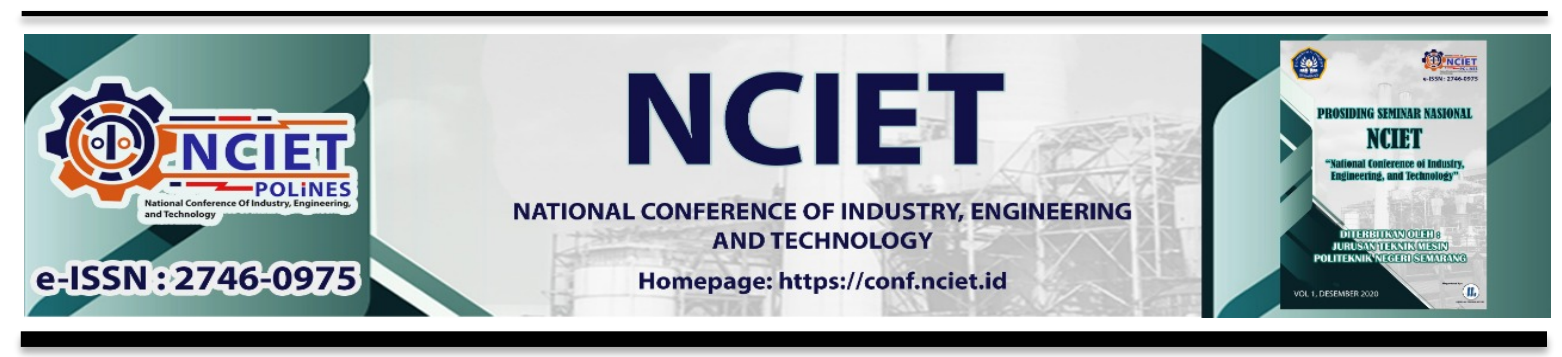

Prosiding Seminar Nasional NCIET Vol.1 (2020) B487-B499

$1^{\text {st }}$ National Conference of Industry, Engineering and Technology 2020,

Semarang, Indonesia.

\title{
RANCANG BANGUN MEDIA PEMBELAJARAN MOTOR BAKAR TORAK EMPAT LANGKAH BERBAHAN BAKAR BENSIN
}

\author{
Akbar Naro Parawangsa ${ }^{1 *}$ Ishak $^{2}$ \\ ${ }^{1}$ Program Studi Perawatan dan Perbaikan Mesin, Politeknik Bosowa \\ J1. Kapasa Raya No. 12, Makassar, 90241 \\ ${ }^{2}$ Program Studi Mekatronika, Politeknik Bosowa \\ Jl. Kapasa Raya No. 23, Makassar, 90241 \\ *E-mail: akbar.naro@politeknikbosowa.ac.id
}

\begin{abstract}
Abstrak
Media pembelajaran memiliki peran penting dalam meningkatkan semangat belajar peserta didik yang perlu menjadi prioritas para pengajar terutama di bidang pendidikan tinggi vokasi. Media pembelajaran yang selaras dengan pendidikan vokasi telah dikembangkan oleh setiap pengajar sekaligus peneliti di lingkungan Politeknik Bosowa. Media Pembelajaran yang dikembangkan berupa rancang bangun motor bakar torak empat langkah sebagai media pembelajaran di mata kuliah mesin kalor dan motor bakar. Penelitian ini bertujuan membuat suatu media pembelajaran untuk memudahkan praktikan yang ada di Politeknik Bosowa dalam melakukan praktikum motor bakar dan lebih mengetahui mekanisme kerja torak, mekanisme katup, pengapian secara langsung pada ruang bakar dan fungsi komponen sistem pendingin. Selain itu media pembelajaran tetap dapat di overhaul. Metode yang digunakan adalah metode rancang bangun, dimana mesin motor bakar Daihatsu Zebra Esspass dengan tipe 4 langkah, 4 silinder, dengan pengapian konvensional dilakukan pemotongan pada bagian blok silinder, kepala silinder, karter dan bagian lain yang dapat dilakukan pemotongan sebagian, kemudian penggunaan motor listrik dan reducer sebagai penggerak utama mesin. Pengaktifan sistem pengapian dirangkai sesuai diagram pengapian konvensional. Hasil dari penelitian ini adalah media pembelajaran yang dapat digunakan untuk praktikum motor bakar dimana media pembelajaran ini memperlihatkan langsung mekanisme kerja torak melalui blok silinder, mekanisme katup melalui kop kepala silinder, penyalaan bunga api pada busi pada ruang bakar, komponen sistem pendingin dan komponen komponen lain pada mesin serta dapat digunakan pada praktik overhaul.
\end{abstract}

Kata Kunci: media pembelajara;, motor bakar torak; mesin 4 langkah; overhaul.

\section{PENDAHULUAN}

Media pembelajaran memiliki peran penting dalam meningkatkan semangat belajar peserta didik yang perlu menjadi prioritas para pengajar terutama di bidang pendidikan tinggi vokasi (Tafonao, 2018). Media pembelajaran yang selaras dengan pendidikan vokasi telah dikembangkan oleh setiap pengajar sekaligus peneliti di lingkungan Politeknik Bosowa. Media Pembelajaran yang dikembangkan berupa rancang bangun motor bakar 
torak empat langkah sebagai media pembelajaran di mata kuliah mesin kalor dan motor bakar.

Penelitian tentang media pembelajaran motor bakar sebelumnya (Darsin, 2006) membahas pembelajaran motor bakar 4-langkah namun masih sangat terbilang sederhana selaras dengan perkembangan kurikulum pendidikan saat itu yang masih sistem KBK.

Selain itu pengujian performa motor bakar telah lama diinvestigasi, (Susilo, 2015) meneliti tentang performa motor bakar pada sepeda motor dengan memodifikasi cylinder head. Penelitian selanjutnya (Aprizal, 2018), memaparkan pengujian motor bakar bensin secara spesifik di setiap parameter motor bakar. Jurnal selanjutnya (Efendi \& Rifal, 2018) hanya menginvestigasi performa mesin diesel satu silinder menggunakan metode standar nasional Indonesia 0119:2002. Penelitian tersebut tentu saja memaparkan karakteristik yang berbeda dengan performa motor bakar torak 4 langkah.

Penelitian (Sanata, 2012), memaparkan optimalisasi mesin bensin dengan variasi temperature bahan bakar dimana bahan bakar yang digunakan adalah campuran bensin dan etanol. Penelitian tersebut tentu berbeda dengan penelitian yang akan kami kaji.

Penelitian ini fokus membuat media pembelajaran yang merancang dan merangkai motor bakar torak. Kami fokus mengambangkan mesin bensin 4 langkah, 4 silinder, 16 valve Daihatsu dengan sistem pengapian kovensional yang menggunakan motor listrik sebagai penggerak. Memperlihatkan mekanisme torak dan mekanisme katup dengan metode potongan sebagian pada blok silinder dan kepala silinder, memperlihatkan waktu pengapian pada ruang bakar dengan melihat percikan api yang terjadi pada busi, serta memperlihatkan konstruksi radiator tanpa cairan pendingin.

\section{METODE PENELITIAN}

Media pembelajaran ini menggunakan metode penelitian eksperimen dengan langkahlangkah sebagai berikut:

a. Merancangan media pembelajaran, yang berfokus pada penggunaan mesin dan bahan lain beserta metode pembuatan

b. Menyiapkan alat dan bahan

c. Membuat rangka, yang terdiri dari dudukan mesin, dudukan motor dan speed reducer, dudukan radiator, dudukan reservoir, dudukan aki dan dudukan koil.

d. Membongkar mesin (overhaul) kemudian membersihkan semua komponen. 
e. Memotong bagian mesin yaitu cylinder block, cylinder head, kop cylinder head, carter, water pump, intake dan exhaust, oil filter dan radiator.

f. Mengecat komponen mesin dan bagian pemotongan dengan warna-warna berbeda, bertujuan untuk lebih membedakan komponen.

g. Merakit kembali mesin beserta komponen tambahan seperti mekanisme penggerak yaitu motor listrik dan speed reducer.

h. Merakit sistem pengapian dengan mengikuti rangkaian pengapian konvensional.

i. Melakukan uji coba alat, untuk melihat apakah alat telah mencapai tujuan yang diinginkan

\section{Alat dan Bahan}

\section{Alat}

Tabel 1. Alat yang digunakan

\begin{tabular}{lll}
\hline Alat & Jumlah kebutuhan & Satuan \\
\hline Gerinda duduk & 1 & Unit \\
Gerinda tangan & 1 & Unit \\
Mesin bor & 2 & Unit \\
Kompresor & 1 & Unit \\
Kunci kombinasi & 1 & Set \\
Kunci socket & 1 & Set \\
Kikir & 2 & Pcs \\
Mesin las & 1 & Unit \\
Ragum & 1 & Unit \\
Gergaji besi & 1 & Pcs \\
Meteran & 1 & Pcs \\
Varnier caliver & 1 & Unit \\
Spray gun & 1 & Unit \\
Kuas & 2 & Pcs \\
Sikat baja & 1 & Pcs \\
APD & 1 & Set \\
\hline
\end{tabular}




\section{Bahan}

Tabel 2. Bahan yang dibutuhkan

\begin{tabular}{lll}
\hline Bahan & Jumlah kebutuhan & Satuan \\
\hline Mesin Daihatsu Zebra & 1 & Unit \\
Radiator & 1 & Unit \\
Motor listrik & 1 & Unit \\
Reducer & 1 & Unit \\
Pulley & 2 & Pcs \\
v-belt & 2 & Pcs \\
Saklar & 2 & Pcs \\
Besi hollow 60x40 & 12 & Meter \\
Besi profil L 50x450 & 6 & Meter \\
Aki 12V & 1 & Unit \\
Baut & 15 & Pcs \\
Elektroda & 1 & Dos \\
Mata bor & 1 & Pcs \\
Amplas & 5 & meter \\
Solar & 20 & Liter \\
Cat & 5 & kaleng \\
Kapur & 1 & Pcs \\
Majun & 5 & Lembar \\
Besi hollow 40x40 & 6 & Meter \\
\hline
\end{tabular}

\section{Diagram Alir}

Diagram alir dapat dilihat pada Gambar 1. 


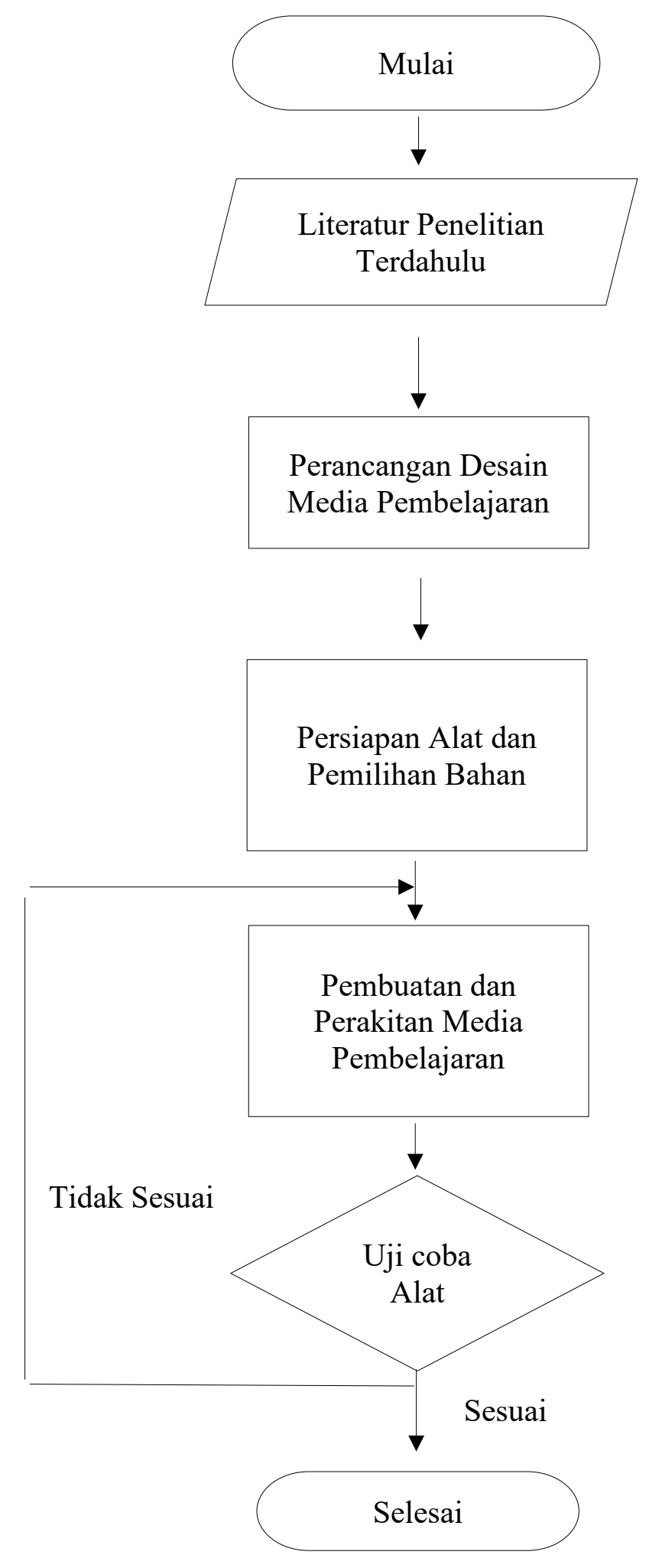

Gambar 1. Diagram alir

\section{Desain Media Pembelajaran}

Desain media pembelajarannya dapat dilihat pada Gambar 2, 3, dan 4. 


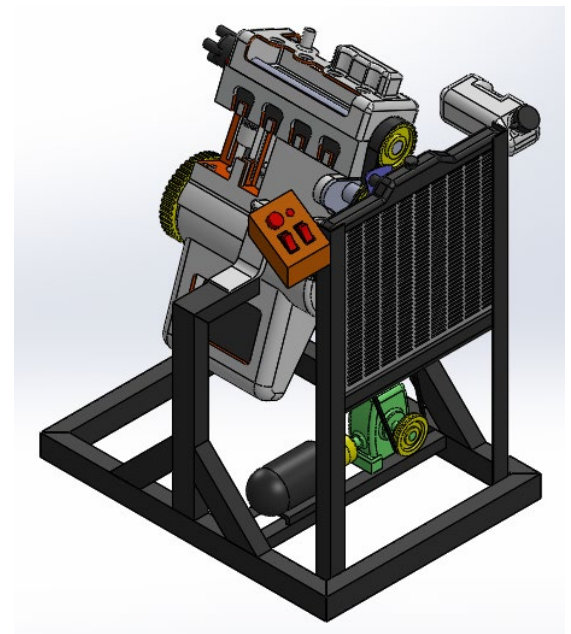

Gambar 2. Desain Media Pembelajaran Tampak Isometrik

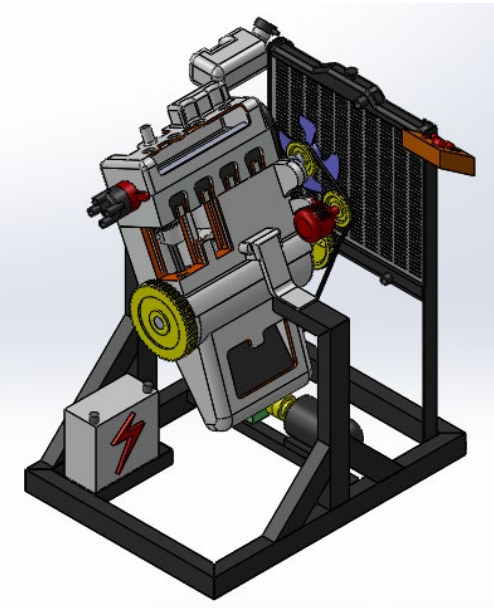

Gambar 3. Desain Media Pembelajaran Tampak Isometric

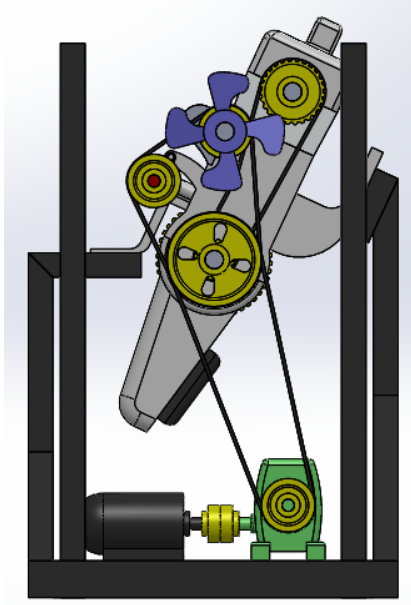

Gambar 2. Desain tampak depan 


\section{HASIL DAN PEMBAHASAN}

\section{Perancangan Alat}

a. Perancangan Rangka

Perancangan rangka media pembelajaran motor bakar ini dimulai dengan melihat bentuk mesin yang digunakan yaitu mesin Daihatsu Zebra Espass $1300 \mathrm{cc}$, tipe mesin ini adalah tipe mesin segaris dan membujur tetapi perancangan rangka dudukan dibuat agar pergerakan piston dapat diamati dengan baik.

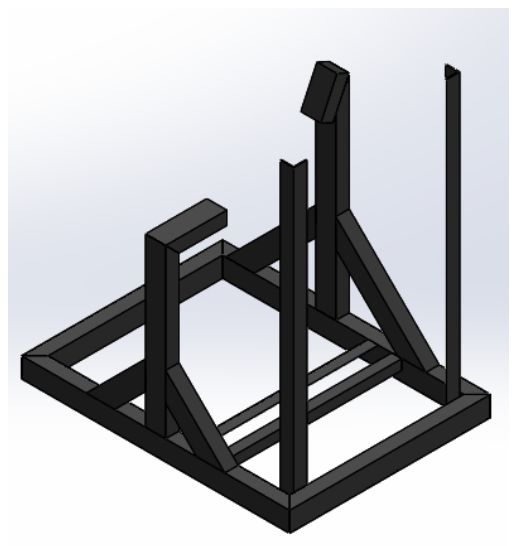

Gambar 5. Rancangan Rangka Media Pembelajaran

b. Perancangan potongan mesin

Pemotongan bagian mesin dilakukan dengan mempertimbangkan antara rumusan masalah penelitian dan kondisi mesin yang digunakan, berdasarkan rumusan masalah maka bagian utama mesin yang akan dipotong atau dibelah adalah bagian cylinder block, bagian intake dan exhaust manifold, bagian carter dan bagian kop cylinder head. Adapun bagian tambahan yang dibelah adalah water pump, filter oil, dan radiator.

c. Perancangan pengapian mesin

Pengapian pada mesin akan diaktifkan dengan batasan hanya memperlihatkan percikan api pada busi tanpa adanya ledakan pada cylinder block. Sumber listrik juga tetap berasal dari aki. Sedangkan perangkaian sistem pengapian mengacu pada rangkaian pengapian konvensional pada umumnya yang terdiri dari aki, switch on/off, koil, distributor, kondenser, dan busi. Perancangan penggerak mesin

Pergerakan naik turun piston dirancang bergerak pelan agar langkah kerja dapat terlihat jelas, dengan begitu penggerak yang dipilih adalah motor listrik AC yang 
putarannya akan dikurangi oleh penggunaan speed reducer. Keluaran dari speed reducer ini akan memutar pulley crankhaft yang telah diganti dengan pulley 2 jalur. Rancangan putaran crankshaft sebesar $\pm 25 \mathrm{rpm}$. Adapun elemen transmisi yang digunakan adalah $v$-belt yang akan meneruskan putaran dari speed reducer menuju ke pulley crankshaft.

\section{Pembuatan Alat}

Setelah perancangan, selanjutnya proses pembuatan alat. Dimana penelitian ini menggunakan mesin Daihatsu Zebra Esspass 1,3 dengan spesifikasi sebagai berikut,

Tabel 3. Spesifikasi Mesin [6]

\begin{tabular}{ll}
\hline Item & Keterangan \\
\hline Jenis mesin & Bensin \\
Jumlah silinder dan penempatan & 4 silinder, segaris, membujur \\
Mekanisme katup & Penggerak belt SOHC \\
Ukuran mesin PxLxT & $683 \times 714 \times 466$ \\
Sistem bahan bakar & Karburator \\
Sistem pengapian & Busi \\
Urutan pengapian & $1-3-4-2$ \\
\hline
\end{tabular}

a. Pemotongan Bagian Mesin

Sebelum melakukan pemotongan terlebih dahulu dilakukan pembongkaran mesin untuk membersihkan bagian bagian yang akan dipotong. Selain itu overhaul ini juga berguna untuk melihat bagian mana yang dapat dipotong dan tidak dapat dipotong serta mengecek kondisi komponen-kompenen mesin. Pembongkaran atau overhaul ini dilakukan berdasarkan Manual Book Daihatsu Zebra Espass. Komponen pemotongan mesin meliputi; pemotongan carter, pemotongan cylinder block, pemotongan cylinder head, pemotongan kop cylinder head, pemotongan Intake manifold dan Exhaust manifold, pemotongan oil filter, pemotongan water pump, pemotongan pipa thermostat, pemotongan radiator.

b. Pengecatan Komponen

Pengecatan dilakukan untuk lebih membedakan komponen beserta bagian yang telah dipotong. Adapun pembagian warna komponen adalah sebagai berikut: 
Tabel 4. Pembagian Warna Komponen

\begin{tabular}{ll}
\hline Warna & Nama komponen \\
\hline Hitam & Rangka, motor penggerak, tuas engkol, dan klem Koil \\
Silver & Cylinder block, cylinder head, kop Cylinder Head, Carter \\
& (Bagian utama mesin) \\
Biru & Intake Manifold, water pump, pipa thermostat, kipas \\
& radiator, (Bagian yang dilalui udara dan air) \\
Merah & Exhaust Manifold, Koil, Alternator (Bagian pembuangan \\
& dan pengapian) \\
Kuning & Pulley, Kopling, Flywheel (Bagian penggerak) \\
Hijau & Oil pump, Oil Filter \\
Jingga & Potongan Mesin, Panel (Bagian pemotongan) \\
\hline
\end{tabular}

Pengecatan ini menggunakan metode semprot menggunakan kompressor dan spray gun. Terlebih dahulu menutup bagian yang tidak diinginkan terkena cat menggunakan selotip kertas. Sedangkan untuk pengecatan potongan dilakukan dengan menggunakan kuas karena permukaan yang sempit. Setelah seluruh bagian komponen dicat, selanjutnya melakukan kegiatan finishing dengan menyemprotkan cairan clear untuk mencegah kotoran menempel dan menambah daya tahan cat.

c. Perakitan Mesin

Perakitan kembali dilakukan setelah pemotongan bagian-bagian mesin dan pengecatan selesai, perlu diperhatikan semua komponen yang tidak dicat terlebih dahulu dicuci dan direndam dengan menggunakan cairan solar bertujuan menghilangkan kotoran pada komponen.

d. Pemasangan Penggerak Mesin

Memasang penggerak mesin dapat dilakukan dengan langkah sebagai berikut.

1. Memasang speed reducer pada dudukannya lalu pasang baut dan kencangkan.

2. Memasang speed reducer beserta dudukannya ke dudukan pada rangka dengan melapisi karet antara dudukan speed reducer dan dudukan pada rangka. Selanjutnya pasang baut dan pastikan masih dalam keadaan kendur. Pastikan baut adjust berada ditengah diantara kedua dudukan speed reducer. 
3. Memasang motor listrik pada dudukan dengan shaft motor listrik segaris dengan shaft input reducer.

4. Memasang v-belt A47 pada pulley crankshaft dan pulley output speed reducer, kemudian atur ketegangan belt dengan menggeser speed reducer menggunakan baut adjust.

5. Menggeser motor listrik hingga kopling shaft motor dan reducer saling mencekam.

6. Mengencangkan baut adjust dan baut pengikat pada dudukan.

e. Perangkaian Sistem Pengapian.

Pengapian pada mesin akan diaktifkan dengan batasan hanya memperlihatkan percikan api pada busi tanpa adanya ledakan pada cylinder block. Sumber listrik juga tetap berasal dari aki. Sedangkan perangkaian sistem pengapian mengacu pada rangkaian pengapian konvensional pada umumnya yang terdiri dari aki, switch on/off, koil, distributor, kondenser, dan busi.

\section{HASIL DAN PEMBAHASAN}

\section{Hasil Penelitian}

Berdasarkan proses dan langkah yang ditempuh dalam pembuatan media pembelajaran motor bakar torak, berikut merupakan hasil penelitian rancang bangun media pembelajaran motor bakar torak empat langkah berbahan bakar bensin.

a. Mesin motor bakar torak 4 silinder, 4 tak, 16 valve dengan pengapian konvensional yang telah dilakukan proses pemotongan pada bagian tertentu.

b. Visualisasi mekanisme kerja mesin empat 4 tak dan 4 silinder dengan pergerakan crankshaft $\pm 25 \mathrm{rpm}$.

c. Visualisasi mekanisme 16 valve dengan tipe Single Over Head Camshaft (SOHC)

d. Rangkaian sistem pengapian konvensional yang terdiri dari aki, saklar, koil, distributor, kabel tegangan tinggi dan busi.

e. Komponen sistem pendingin yang terdiri dari radiator, kipas, thermostat, reservoir, selang dan water pump.

f. Motor listrik AC 220 Volt dengan daya 0,5 HP dan kecepatan $2800 \mathrm{rpm}$ sebagai sumber penggerak yang dikopel dengan speed reducer. 
g. Speed reducer tipe WPA 50 dengan rasio 1:60 dan daya $2 \mathrm{~kW}$ sebagai pengurang putaran, penambah daya dan penggerak mesin.

h. Aki 12 volt sebagai sumber listrik DC sistem pengapian.

i. Rangka mesin yang terdiri dari dudukan mesin, dudukan motor, dudukan speed reducer, dudukan aki, dudukan radiator dan reservoir.

j. $\quad$ Pulley dan $v$-belt sebagai pemindah tenaga dari speed reducer ke pulley crankshaft.
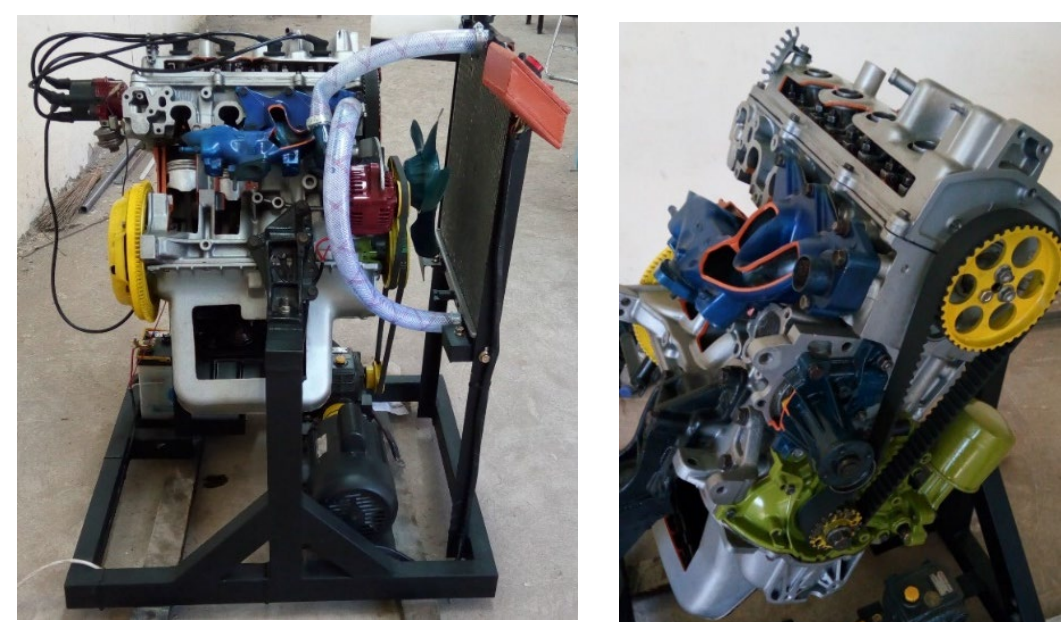

Gambar 6. Hasil Penelitian

\section{Pembahasan}

Pada media pembelajaran ini yang menggunakan mesin motor bakar torak dengan 4 silinder dengan 4 langkah kerja memiliki urutan pengapian 1-3-4-2 dalam hal ini keempat silinder tidak memiliki langkah kerja yang sama walaupun posisi piston 1 dan 4 , posisi piston 2 dan 3 pada posisi yang sama.

Jika analisa langkah kerja piston berpatokan pada langkah kerja piston 1 maka saat silinder 1 meledak yang dimulai dari posisi piston pada TMA, piston akan bergerak turun dan mengalami langkah usaha. Disisi lain piston 4 juga bergerak turun tetapi mengalami langkah isap. Piston 2 dan 3 bergerak naik tetapi piston 2 mengalami langkah buang sedangkan piston 3 mengalami langkah kompresi.

Setelah peledakan pada silinder 1 maka selanjutnya peledakan akan terjadi pada silinder 3 yang mengalami langkah kompresi. Saat piston 3 kembali turun dengan langkah usaha maka piston 2 juga bergerak turun dengan langkah isap. Disisi lain piston 1 dan 4 bergerak naik dengan piston 1 mengalami langkah buang dan piston 4 dengan 
langkah kompresi. Setelah peledakan pada silinder 3, selanjutnya peledakan terjadi pada silinder 4 yang mengalami langkah kompresi.

Selanjutnya piston 1 dan 4 bergerak turun dengan piston 1 mengalami langkah isap dan piston 4 mengalami langkah usaha. Pada silinder 2 dan 3, piston bergerak naik dengan piston 2 mengalami langkah kompresi dan piston 3 mengalami langkah buang, dengan begitu peledakan selanjutnya akan terjadi pada silinder 2 yang mengalami langkah kompresi. Setelah silinder 2 meledak dan piston 2 dan 3 bergerak turun dengan piston 2 mengalami langkah usaha dan piston 3 mengalami langkah isap, pada silinder 1 dan 4 piston bergerak naik sehingga piston 4 mengalami langkah buang sedangkan piston 1 mengalami langkah kompresi. Saat piston 1 mencapai TMA maka siklus baru dimulai.

Untuk mempermudah analisa berikut tabel langkah kerja piston.

Tabel 5. Piston 1 Langkah Usaha

\begin{tabular}{|c|c|c|c|c|}
\hline Langkah kerja & Piston 1 & Piston 2 & Piston 3 & Piston 4 \\
\hline Langkah isap & & & & \\
\hline Langkah kompresi & & & & \\
\hline Langkah usaha & & & & \\
\hline Langkah buang & & & & \\
\hline
\end{tabular}

Tabel 6. Piston 3 Langkah Usaha

\begin{tabular}{l|l|l|l|l}
\hline Langkah kerja & Piston 1 & Piston 2 & Piston 3 & Piston 4 \\
\hline Langkah isap & & & & \\
Langkah kompresi & & & & \\
Langkah usaha & & & & \\
Langkah buang & & & & \\
\hline
\end{tabular}

Tabel 7. Piston 4 Langkah Usaha

\begin{tabular}{l|l|l|l|l}
\hline Langkah kerja & Piston 1 & Piston 2 & Piston 3 & Piston 4 \\
\hline Langkah isap & & & & \\
\hline
\end{tabular}




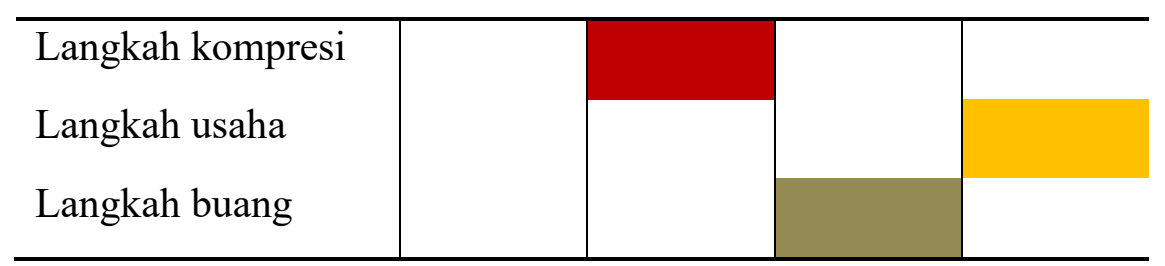

Tabel 8. Piston 2 Langkah Usaha

\begin{tabular}{l|l|l|l|l}
\hline Langkah kerja & Piston 1 & Piston 2 & Piston 3 & Piston 4 \\
\hline Langkah isap & & & & \\
Langkah kompresi & & & & \\
Langkah usaha & & & & \\
Langkah buang & & & & \\
\hline
\end{tabular}

\section{KESIMPULAN}

Berdasarkan hasil rancang bangun media pembelajaran motor bakar torak empat langkah berbahan bakar bensin maka dapat disimpulkan bahwa:

1. Media pembelajaran dapat digunakan untuk membantu praktikan dalam melakukan praktikum motor bakar.

2. Media pembelajaran dapat membantu praktikan untuk mengetahui langsung mekanisme kerja torak, mekanisme katup, fungsi komponen sistem pendingin dan pengapian secara langsung pada ruang bakar mesin empat langkah kendaraan ringan berbahan bakar bensin.

\section{DAFTAR PUSTAKA}

Aprizal. (2018). Uji Prestasi Motor Bakar Bensin Merek Honda Astrea 100 CC. Jurnal Fakultas Teknik Universitas Pasir Perairan, 1, 6-14.

Darsin, M. (2006). Pembuatan Alat Peraga Motor 4-Langkah Untuk Mendukung Pembelajaran Sistem KBK. Pengembangan Pendidikan, 3(1), 44-55.

Efendi, Y., \& Rifal. (2018). Uji Performa Mesin Diesel Satu Silinder Menggunakan Metode Standar Nasional Indonesia (SNI) 0119:2012. Motor Bakar: Jurnal Teknik Mesin Universitas Muhammadiyah Tangerang, 2(1), 1-7.

Sanata, A. (2012). Optimalisasi Prrestasi Mesin Bensin Dengan Variasi Temperatur. Rotor, $1-7$.

Susilo, J. (2015). Modifikasi Cylinder Head Terhadap Unjuk Kerja Sepeda Motor. Jurnal Teknik Mesin UBL, 19-23.

Tafonao, T. (2018). Peranan Media Pembelajaran Dalam Meningkatkan Minat Belajar Mahasiswa. Jurnal Komunikasi Pendidikan, 2(2), 103-114. 